\title{
PENGGUNAAN CITRA QUICKBIRD DAN SIG \\ UNTUK PEROLEHAN DATA SPASIAL GUNA MENDUKUNG MANAJEMEN \\ LALULINTAS DI KOTA YOGYAKARTA
}

\author{
Oleh: \\ Qadriathi Dg. Bau dan Hartono \\ Program Studi S2 Penginderaan Jauh \\ Fakultas Geografi UGM
}

\begin{abstract}
Abstrak
Permasalahan yang sering muncul di pusat kota pada kota-kota vesar dan menengah, seperti halnya Yogyakarta adalah masalah transportasi yang pada umumnya terjadi akibat ketimpangan antara kepesatan peningkatan sarana transportasi dan rendahnya kemampuan penyediaan prasarana transportasi.

Citra Quickbird dapat digunakan untuk menyajikan data dan informasi beberapa parameter yang berkaitan dengan kemacetan lalulintas sehingga dapat digunakan untuk manajemen lalulintas dalam pemecahan masalah transportasi. Data dari 8 parameter yang digunakan sebagai masukan dalam manajemen lalu lintas, 5 parameter dapat diinterpretasi dari citra Quickbird, yaitu: unsur geometrik jalan yang dipakai sekagai dasar dalam perhitungan tingkat pelayanan dan derajat kejenuhan, penggunaan lahan, bentuk persimpangan, trotoar, dan kondisi parkir. Data spasial yang diperoleh memiliki akurasi yang baik dengan ketelitian 98\% masing-masing untuk penggunaan lahan dan data lebar jalan.
\end{abstract}

Kata Kunci: Quickbird, SIG, Kemacetan Lalulintas, Manajemen Lalulintas

\section{Pendahuluan}

Perkembangan kehidupan di kota bersifat dinamis, pertumbuhan penduduk merupakan salah satu faktor yang dominan dalam dinamika 

Penggunaan Citra Quickhird dan SIG Untuk Perolehan Data Spasial Guna Mendukung Manajemen Lalulintas di Kota Yogyakarta

kehidupan kota. Seiring dengan pertambahan tersebut bertambah pula tuntutan terhadap tersedianya fasilitas pemenuhan kebutuhan. Terjadinya peningkatan kebutuhan penduduk yang tidak diimbangi dengan pembangunan fasilitas peningkatan kebutuhan akan menyebabkan ketidakseimbangan dalam kehidupan kota, dan hal ini akhirnya melahirkan masalah. Permasalahan yang mudah terlihat di pusat kota adalah masalah transportasi yang pada umumnya terjadi akibat ketimpangan antara kepesatan peningkatan sarana transportasi dan rendahnya kemampuan penyediaan prasarana transportasi. Pertumbuhan ekonomi dan jumlah penduduk yang besar menyebabkan meningkatnya aktivitas pemenuhan kebutuhan yang tentunya meningkatkan pula kebutuhan akan angkutan. Pertambahan permintaan angkutan cenderung ditampung dengan penyelesaian secara individual, yaitu pemakaian tiendaraan secara perorangan ini di satu pihak akan menguntungkan, akan tetapi di pihak lain akan menimbulkan masalah lalulintas (Tamin, 2000).

Pemakaian kendaraan secara perseorangan mempunyai sisi positif bagi pengendara dalam hal mobilitas pergerakannya yaitu semakin banyak aktivitas yang dapat dijalani tanpa harus berpindah dari moda yang satu ke moda yang lain, dan sisi negatifnya adalah bertambahnya kendaraan di jalan yang jumlahnya tidak dibatasi dapat menimbulkan masalah lalulintas seperti kemacetan. Selain itu, kemacetan juga terjadi karena kondisi jalan dan kondisi sistem prasarana transportasi yang tidak berfungsi secara optimal, oleh karena adanya kegiatan-kegiatan nonformal yang menyebabkan penurunan kapasitas jalan, misalnya penggunaan trotoar oleh pedagang kaki lima ataupun kegiatan parkir pada badan jalan yang akan berakibat pada makin parahnya tingkat kemacetan.

Penelitian tentang potensi kemacetan lalulintas selama ini dilakukan dengan metode survai lapangan dan hasil perhitungan, dimana proses tersebut misalnya wawancara dapat mengganggu pengguna jalan dan menimbulkan tundaan lalulintas jika yang dijadikan responden adalah para pemakai jalan dan hal tersebut akan membutuhkan waktu yang cukup lama, selain itu pemilihan metode survai pengumpulan data juga sangat tergantung dari ketersediaan surveyor. Dengan demikian galat teknis dan galat yang timbul akibat faktor manusia sering terjadi, misalnya galat mencatat dan menafsirkan. Oleh sebab itu dibutuhkan suatu metode alternatif yaitu dengan menggunakan teknik penginderaan jauh dalam hal ini citra Quickbird diintegrasikan dengan SIG karena citra Quickbird memiliki resolusi spasial yang sangat tinggi dan memiliki gambaran 
piktorial yang baik dan menyerupai foto udara sehingga dapat dipakai untuk membantu penelitian di bidang lalulintas khususnya dalam menyadap data jalan dan lingkungan jalan sehingga waktu dan biaya operasional penelitian dapat diminimalkan.

SIG adalah sistem komputer yang digunakan untuk memanipulasi data geografi. Sistem ini diimplementasikan dengan perangkat keras dan perangkat lunak komputer yang berfungsi untuk: (a) akusisi dan verifikasi data, (b) kompilasi data, (c) penyimpanan data, (d) perubahan dan updating data, (e) manajemen dan pertukaran data, (f) manipulasi data, (g) pemanggilan dan presentasi data, dan ( $h$ ) analisa data (Bernhardsen, 1992 dalam Prahasta, 2002). Pengertian lain menyebutkan SIG adalah teknologi informasi yang menganalisis, menyimpan, menayangkan baik data keruangan dan non keruangan dan SIG adalah sistem informasi yang mendasarkan pada kerja dasar komputer yang mampu memasukkan, mengelola (memberi dan mengambil kembali, memanipulasi dan analisis data, dan memberi uraian) (Aronoff, 1989 dalam Dulbahri, 2003).

SIG dan penginderaan jauh merupakan dua teknologi yang dapat diintegrasikan untuk mendapatkan informasi baru, baik berupa data spasial maupun data atribut secara akurat dan cepat. Dalam perkembangan selanjutnya SIG banyak diimplementasikan pada daerah perkotaan karena daerah perkotaan mengalami perubahan yang sangat cepat sehingga diperlukan sarana yang mampu memantau tingkat perubahan yang terjadi. Dalam pengelolaan Ialulintas perkotaan hal yang perlu mendapat perhatian adalah identifikasi variabel yang relevan dengan masalahnya serta terjalinnya keterkaitan antara data non spasial dan data spasial dan dengan pemanfaatan SIG dapat dilakukan dengan mudah.

\section{Kondisi Wilayah}

Wilayah Kota Yogyakarta dengan luas $32,5 \mathrm{~km}^{2}$ menjadi daerah tujuan utama bagi pariwisata, pendidikan, dan sektor lain. Sektor pariwisata adalah sektor andalan bagi Kota Yogyakarta disamping sektor pendidikan dan jasa. Kecenderungan yang ada sekarang menunjukkan bahwa Kota Yogyakarta telah dan sedang beraglomerasi membentuk suatu area perkotaan yang lebih besar dengan jumlah penduduk pada tahun 2000 sebesar 397.398 jiwa dengan kepadatan penduduk 12.228 jiwa/ $\mathrm{km}^{2}$ (BPS, 2003). Hal tersebut membawa dampak pada semakin beratnya beban Kota Yogyakarta dalam memberikan pelayanan bagi 
Penggunaan Citra Quickbird dan SIG Uniuk Perolehan Data Spasial Guna Mendukung Manajemen

Lalulintas di Kota Yogyakarta

penduduk yang ada di dalamnya termasuk dalam hal pelayanan transportasi. Sektor pendidikan dan jasa ditenggarai merupakan penyebab semakin kuatnya tarikan Kota Yogyakarta terhadap daerah-daerah lain selain yang bisa disebutkan salah satunya karena alasan budaya (Ahmad Munawar, 2004).

Hal lain yang merupakan daya tarik utama untuk menarik arus urbanisasi yang tinggi disebabkan Kota Yogyakarta dilengkapi dengan berbagai fasilitas yang ada baik itu fasilitas dalam bidang pendidikan maupun fasilitas kerja. Dengan kondisi yang demikian menyebabkan meningkatnya aktivitas pemenuhan kebutuhan untuk melakukan pergerakanpun menjadi semakin meningkat yang tentunya meningkatkan pula kebutuhan akan angkutan.

\section{Metode Penelitian}

Metode penelitian secara umum dikelompokkan merijadi 3 bagian, yaitu:

1. Tahap Persiapan

Tahapan pertama yang dilakukan adalah mengumpulkan dan menyiapkan bahan kepustakaan dan peta yang berhubungan dengan daerah penelitian, mengumpulkan dan mencari bahan serta alat yang diperlukan dalam pelaksanaan penelitian, dan mempersiapkan dasar klasifikasi tentang data-data yang akan diolah.

2. Tahap Pelaksanaan, meliputi;

a. Tahap interpretasi citra Quickbird, yaitu membatasi daerah penelitian dengan bantuan peta administrasi Kota Yogyakarta skala 1 : 10.000, interpretasi penggunaan lahan, kondisi parkir, trotoar, dan jaringan jalan meliputi unsur geometrik jalan dan bentuk persimpangan.

b. Tahap kerja lapangan, dilakukan untuk menguji validitas data yang disadap dari citra Quickbird yang sekaligus berfungsi sebagai perbaikan, pembaharuan data sebagai akibat selisih waktu perekaman dengan waktu penelitian, membuktikan kebenaran hasil interpretasi, melakukan proses penilaian atau perhitungan terhadap parameter-parameter yang telah ditentukan pada lokasi sampel, dan pengumpulan data baru yang tidak dapat disadap dari citra Quickbird. 
c. Tahap pemrosesan data, data-data yang telah diperoleh selanjutnya diproses menggunakan SIG untuk mencapai tujuan penelitian ini yaitu peta potensi kemacetan lalulintas. Prosesnya meliputi: (1) Perhitungan kapasitas dasar dengan menggunakan formula Manual Kapasitas Jalan Indonesia (MKJI, 1997) dimana variabelnya diperoleh dari interpretasi citra dan dari kerja lapangan serta data sekunder, dan (2) Penilaian parameter fisik jalan dan lingkungan jalan, dimana data yang diperlukan yaitu data grafis jaringan jalan diperoleh dari interpretasi citra serta data atribut dari lalulintas harian rata-rata, tingkat pelayanan jalan, derajat kejenuhan, penggunaan lahan, bentuk persimpangan, trotoar, kondisi perparkiran, dan rambu.

3. Tahap Penyelesaian

Pada tahap ini, dilakukan pengharkatan (pemberian bobot) terhadap parameter-parameter penyebab kemacetan- lalulintas. Harkat tinggi diberikan kepada setiap parameter yang pengaruhnya besar terhadap terjadinya kemacetan lalulintas sesuai dengan tingkatannya meliputi penggunaan lahan, kondisi perparkiran, lalulintas harian rata-rata, rambu, tingkat pelayanan jalan, bentuk persimpangan, derajat kejenuhar, dan trotoar; sebaliknya harkat rendah jika pengaruh setiap parameter terhadap terjadinya kemacetan kecil. Cara yang demikian disebut pemodelan spasial dengan pendekatan kuantitatif berjenjang kemudian dilakukan analisis hasil perhitungan dan keluaran data disajikan dalam bentuk peta potensi kemacetan lalulintas. Berdasarkan peta tersebut kemudian dianalisis penyebab kemacetan lalulintas pada ruas jalan yang diteliti dan memberi alternatif pemecahan masalah kemacetan Ialulintas.

\section{Hasll Penelitian dan Pembahasan}

Data yang diperoleh darl interpretasi citra Qulckbird meliputi JarIngan Jalan, penggunaan lahan, bentuk persimpangan, trotoar, kondlsi parkir, dan unsur geometrik jalan; sedangkan data yang tidak dapat dlsadap dari citra dlperoleh melalui pengukuran di lapangan meliputi rambu, volume lalu lintas, hambatan samping, dan kecepatan. rata-rata kendaraan. 
Penggunaan Citra Quickbird dan SIG Untuk Perolehan Data Spasial Cuna Mendukung Manajemen

Lalulintas di Kota Yogyakarta

\section{Pemetaan Jaringan Jalan}

Interpretasi jaringan jalan dilakukan secara visual pada layar menggunakan perangkal lunak ArcView 3.2 dengan memperhatikan unsurunsur interpretasi citra. Acuan dalam interpretasi adalah peta administrasi Kota Yogyakarta skala 1: 10.000 tahun 1989 serta ditunjang oleh pengetahuan lokal sehingga mempermudah untuk mengetahui nama-nama jalan yang dapat dirdentifikasi pada citra Quickbird.

Citra Quickbird yang digunakan dalam penelitian sudah terkoreksi geometrik dan radiometrik dengan resolusi spasial 2,44 $\mathrm{m}$ dan dalam format digital membantu untuk melihat kenampakan jalan di seluruh Kota Yogyakarta. Informasi jaringan jalan yang diperoleh juga dipakai untuk mengetahui dan menunjukkan semua jalan yang berpotensi mengalami kemacetan Ialulintas. Adapun peta jaringan jalan dapat dilihat pada Gambar 1.

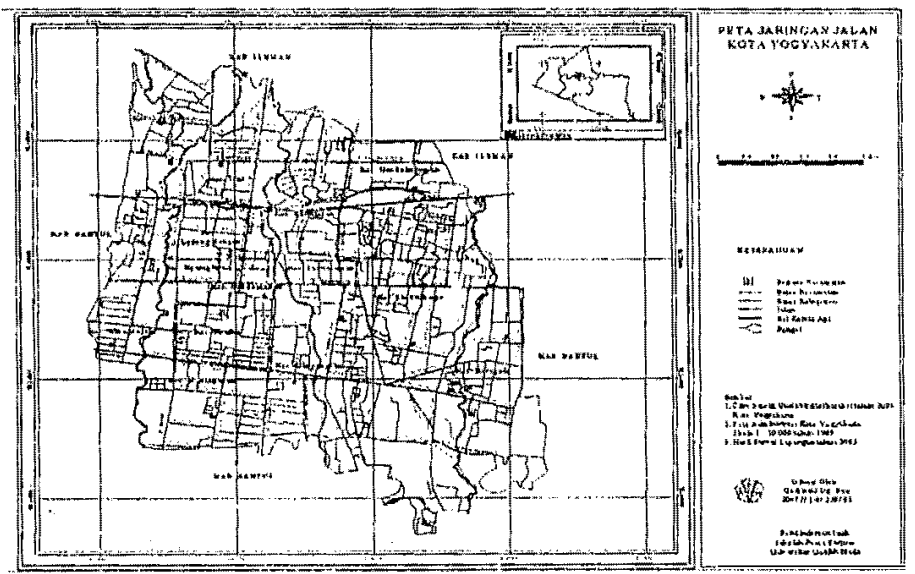

Gambar 1. Peta Jaringan Jalan

\section{Pemetaan Penggunaan Lahan}

Berdasarkan hasil interpretasi citra Quickbird dan didukung oleh resolusi spasial citra yang tinggi membantu dalam interpretasi kenampakan individual tiap obyek penggunaan lahan. Didukung kerja lapangan maka 
dapat diketahui jenis dan komposisi penggunaan lahan di daerah penelltian sesuai klaslfikasl menurut Malinggreau (1982), kemudian disesuaikan dengan MKJI (1997) untuk selanjutnya dilakukan matriks uji ketelitian terhadap penggunaan lahan tersebut. Informiasi penggunaaı lahan yang diperoleh, digunakan sebagai salah satu parameter yang berpengaruh terhadap kemacetan Ialulintas. Makin tinggi tingkat aktivitas suatu penggunaan lahan, makin tinggi pula tingkat potensi macetnya. Berdasarkan hasil interpretasi citra Quickbird dengan resolusi spasial citra yang tinggi membantu dalam interpretasi kenampakan individual tiap obyek penggunaan lahan dan diperlihatkan pada Gambar 2 dan Gambar 3.

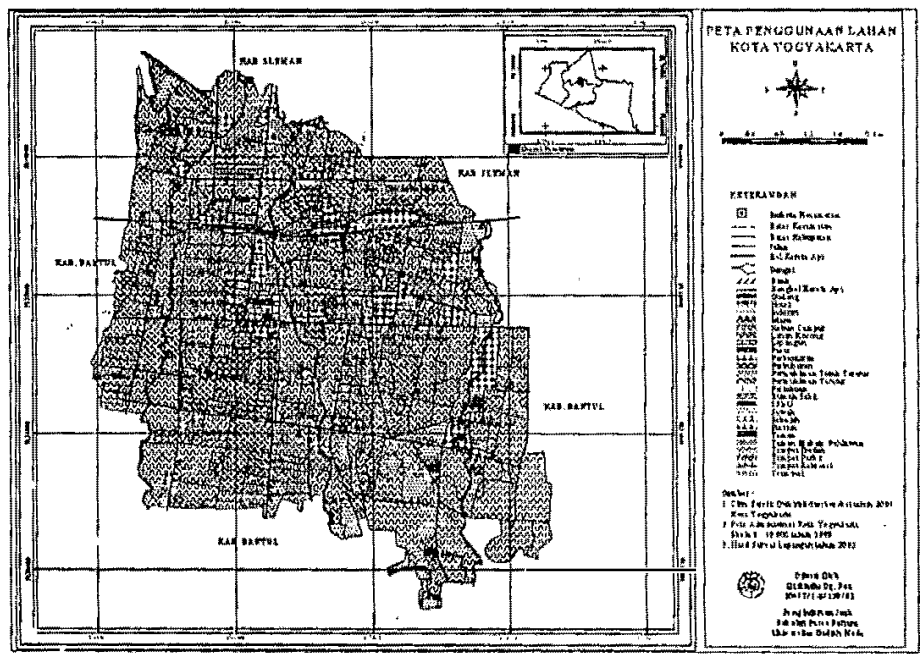

Gambar 2. Peta Penggunaan Lahan 


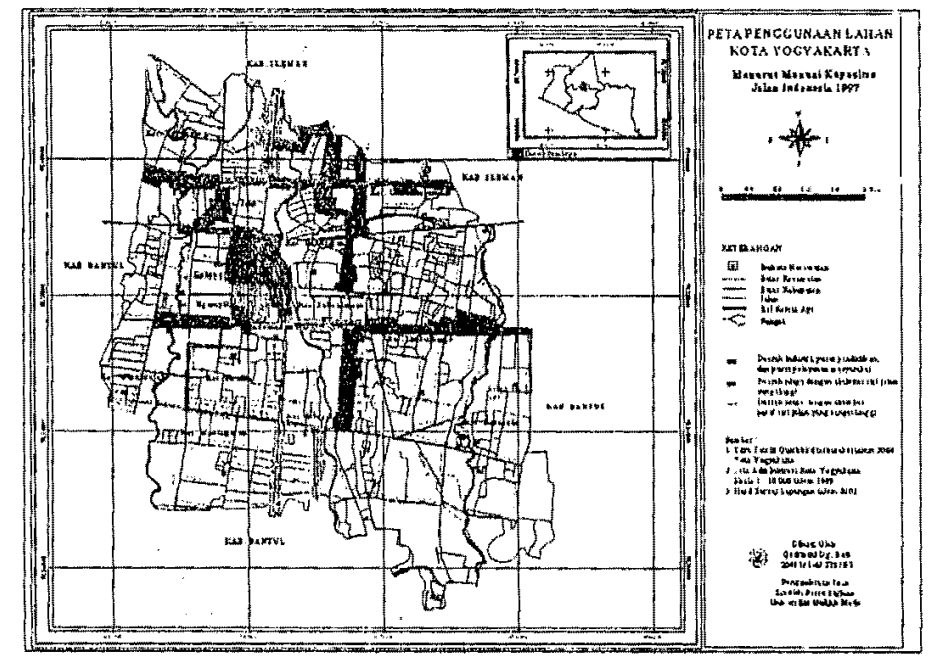

Gambar 3. Peta Penggunaan Lahan menurut MKJI (1997)

\section{Perhitungan Potensi Kemacetan Lalulintas}

Volume lalulintas pagi hari dihitung mulai pukul 06.00 Wita sampai pukul 08.00 Wita. Volume lalulintas untuk setiap jalan yang diteliti memperlihatkan kondisi volume kendaraan rata-rata adalah 2.000 $\mathrm{smp} / \mathrm{jam}$ sampai $9.000 \mathrm{smp} / \mathrm{jam}$. Jenis yang dihitung meliputi sepeda motor, kendaraan ringan, truk, dan bus dan jenis moda yang mendominasi yaitu sepeda motor, sedangkan becak, andong, dan manusia tidak dimasukkan dalam perhitungan sebab termasuk hambatan samping sesuai dengan MKJI (1997).

Volume lalulintas siang hari dihitung mulai pukul 12.00 Wita sampai pukul 14.00 Wita, dimana terlihat penurunan volume lalulintas pada sebagian jalan walaupun ada sebagian jalan yang mengalami peningkatan dibanding pagi hari. Volume lalulintas sore hari dihitung mulai pukul 16.00 Wita sampai pukul 18.00 Wita. Hal ini dipengaruhi oleh adanya kegiatan yang diakhiri pada jam tersebut, seperti perkantoran, lembaga swasta, dan sebagian pertokoan sehingga ada sebagian jalan terjadi perubahan volume laluliritas. 
Faktor koreksi kapasitas ditentukan berdasarkan lebar jalan efektif. Lebar jalan juga dapat diukur dari citra Quickbird. Median merupakan jalur yang terletak di tengah jalan untuk membagi jalan tiap arah. Adanya median, maka lalulintas dari dua arah terdistribusi merata dan tidak mengganggu arus lalulintas dari arah yang berlawanan, pembagiannya biasanya 50\%: 50\%. Khusus untuk ruas jalan satu arah, maka distribusi lalulintasnya 100\%: $0 \%$. Hambatan samping yang dimaksudkan yaitu kegiatan perparkiran yang dapat mengurangi kemampuan jalan tersebut dalam menampung arus kendaraan yang lewat sehingga mengurangi lebar efektif ruas jalan.

Jumlah penduduk yang dipakai dalam perhitungan faktor koreksi kapasitas akibat ukuran kota sebesar 397.398 jiwa (BPS, 2003). Berdasarkan jumlah penduduk Kota Yogyakarta tersebut maka faktor penyesuaian ukuran kota adalah 0,90. Berdasarkan hasil perhitungan untuk kapasitas, datanya diperoleh dari hasil interpretasi citra dan survai lapangan, maka diperoleh kapasitas jalan pagi, siang, dan sore hari pada pengamatan pertama, kedua, dan ketiga.

Lalulintas harian rata-rata adalah volume lalulintas dalam satu hari yang merupakan gambaran perkiraan kendaraan yang melewati suatu jalan dalam satu hari. Pada penelitian ini, lalulintas harian rata-rata yang digunakan yaitu data total volume lalulintas puncak hasil pengamatan pagi, siang, dan sore hari semua moda dan diketahui jumlah kendaraan yang Iewat satu hari antara $8.600 \mathrm{smp}$ sampai $47.600 \mathrm{smp}$. Tingkat pelayanan jalan sebagai salah satu variabel untuk menghitung tingkat kemacetan lalulintas diperoleh dari kerja lapangan dengan membagi antara nilai volume lalulintas hasil pengukuran pada hari pertama, kedua, dan ketiga untuk masing-masing waktu pengamatan dengan nilai kapasitas jalannya. Nilai DS pada penelitian ini diperoleh dari perbandingan nilai arus lalulintas jam puncak rata-rata dengan nilai kapasitas yang diperoleh dari hasil perhitungan dan kecepatan rata-rata kendaraan yang diperoleh dari hasil pengamatan lapangan.

Peta penggunaan lahan diperoleh dari hasil interpretasi citra Quickbird, penggunaan lahan yang ditampilkan dibatasi oleh penggunaan Iahan tepi jalan daerah penelitian. Data bentuk persimpangan diperoleh dari interpretasi citra Quickbird dan dibagi dalam tiga kelas, yaitu bentuk persimpangan kanalisasi, persirnpangan simetris, dan persimpangan tidak simetris. Penilaian tentang adanya trotoar pada suatu jalan diperoleh dari 
Perıggunaan Citra Quiclibirs dan S!C Untuk Perolehan Data Spasial Guna Mendukung Manajemen Lalulintas di Kota Yogyakarta

hasil interpretasi citra Quickibird kemudian dicocokkan dengan hasil kerja lapangan. Kegiatan parkir yang dianalisis dalam penelitian ini adalah kegiatan parkir berdasarkan moda transportasi yang terdapat pada ruas jalan yang digunakan untuk parkir. Data rambu diperoleh dari kerja lapangan dan membandingkan dengan tingkat kebutuhan rambu berdasarkan Keputusan Menteri Perhubungan No. 61 Tahun 1993.

\section{Penllalan PotensI Kemacetan Lalullntas}

Parameter yang dipakai sebagai penilaian terhadap potensi kemacetan suatu jalan dibagi menjadi delapan parameter dan diperoleh dari hasil interpretasi citra dan cek lapangan. Penilaian potensi kernacetan lalulintas didasarkan atas hasil total dari penjumlahan masing-masing parameter hasil analisis dan pengolahan data kemudian hasil tersebut dibagi ke dalam tiga kelas, yaitu tinggi, sedang, dan rendah dan dibagi dalam tiga periode waktu yaitu pengamatan pertama mewakili hari senin sampai dengan hari kamis, pengamatan kedua mewakili hari jum'at, dan pengamatan ketiga mewakili hari sabtu.

Pada pengamatan pertama, jalan yang berpotensi macet paling tinggi dengan nilai harkat 21 sampai 24, yaitu: J. Diponegoro, J. Urip Sumohardjo, Jl. Parang Tritis, J. Sisingamangaraja, dan Jl. Gejayan. Pada jalan tersebut lalulintas harian rata-ratanya antara $13.000 \mathrm{smp}$ sampai $24.000 \mathrm{smp}$, tingkat pelayanan jalan lebih dari 1 sehingga dikategorikan dalam kondisi kritis. Derajat kejenuhan yang tinggi di semua jalan, penggunaan lahan tepi jalan berupa pasar tradisional dan pusat pertokoan merupakan daerah bangkitan untuk menarik arus lalulintas pada pagi hari, seringga menimbulkan permasalahan parkir. Kapasitas parkir yang disediakan pada pasar tradisional tidak dapat menampung jurrilah kendaraan yang banyak sehingga mengurangi lebar efektif jalan dan pergerakan keluar masuk kendaraan mengganggu arus lalulintas yang melewati jalan tersebut.

Bentuk persimpangan yang tidak simetris dan trotoar memberi nengaruh terhadap terjadinya kesemrawutan lalulintas, trotoar yang semula diperuntukkan untuk pejalan kaki telah berubah fungsi menjadi tempat usaha bagi pedagang kaki lima sehingga trotoar tidak lagi berfungsi sebagaimana yang diharapkan dan pejalan kaki mengambil badan jalan untuk beraktifitas, dan jumlah ketersediaan rambu di setiap jalan walaupun rata-rata telah Iebih dari $75 \%$ kecuali di ال Sisingamangaraja dan J. 
Gejayan. Akibat kurang tingginya rasa disiplin berlalulintas bagi sebagian masyarakat dan pelanggaran sering terjadi yang menyebabkan kemacetan lalulintas.

Jalan yang berpotensi macet sedang dengan nilai harkat 18 sampai 20 terjadi pada Jl. May. Suryotomo, J. Kyai Mojo, J. Mataram, J. Tentara Pelajar, Jl. A.M. Sangaji, Jl. Kusumanegara, Jl. Dokter Sutomo, J. Prof. Dr. Sarjito, Jl. Prof. Herman Yohanes, Jl. Dr. Wahidin, Jl. Taman Siswa, J. Jend. Sudirman. 1 arah, Jl. Ahmad Yani, Jl. Malioboro, dan J. Suroto dengan karakteristik tingkat pelayanan jalan rata-rata di atas 1 . Penggunaan lahan tepi jalan sebagian besar merupakan pusat pendidikan seperti sekolah, perkantoran, pusat pelayanan masyarakat berupa hotel, laboratorium kesehatan, dan berupa daerah niaga dengan aktifitas sisi jalan yang tinggi seperti pusat pertokoan. Jumlah ketersediaan rambu di setiap jalan walaupun rata-rata telah lebih dari $75 \%$ banyak yang tidak dipatuhi akibat rendahnya disiplin berlalulintas bagi sebagian masyarakat yang berakibat pada kemacetan lalulintas.

Jalan yang berpotensi macet rendah dengan nilai harkat 14 sampai 17, yaitu: Jl. May. Suryotomo, Jl. Mataram, Jl. Cik Ditiro, Jl. Tentara Pelajar, Jl. K.H.A. Dahlan, Jl. Pasar Kembang, Jl. Sultan Agung, Jl. Prof Dr. Sarjito, Jl. Taman Siswa, Jl. Sudirman 1 arah, Jl. Sudirman 2 arah, Jl. Suroto, dan Jl. Terban. Pada jalan tersebut lalulintas harian rata-ratanya antara $7.000 \mathrm{smp}$ sampai $22.000 \mathrm{smp}$, tingkat pelayanan jalannya rata-rata mempunyai nilai zntara 0,3 sampai 0,9 dan arus masih stabil dan jika terjadi penurunan kecepatan maka kondisinya tidak terlalu lama. Penggunaan lahan tepi jalan bervariasi, daerah niaga berupa pasar tradisional seperti di Jl. Sultan Agung tetapi karena volume lalulintas yang melewati jalan tersebut masih sesuai dengan standar perencanaan maka potensi macetnya masih kurang.

Sesuai dengan kelas kemacetan lalulintas dengan tiga waktu pengamatan yang berbeda, ada sebagian jalan yang potensi macet untuk pagi, siang, dan sore hari mengalami perubahan. Jalan tersebut yaitu J May. Suryotomo, Jl. Mataram, Jl. Tentara Pelajar, Jl. Prof. Dr. Sarjito, J. Sudirman 1 arah, dan Jl. Suroto. Perbedaan tersebut disebabkan oleh jumlah volume lalulintas yang melewati jalan tersebut pada tiga waktu pengamatan mengalami perubahan akibat penggunaan lahan yang berada pada jalan tersebut.

Kondisi kemacetan juga disebabkan oleh penyempitan lebar jalan yang tidak bisa menampung arus lalulintas, kondisi ini disebabkan adanya median yang fungsinya untuk mendistribusikan kendaraan secara merata 
Pengrgunaan Citra Quickbiud dan SIC Untuk Perolehan Data Spasial Guna Mendukung Manajemen Lalulintas di Kola Yogyakatta

tetapi fungsi tersebui kurang efektif untuk diterapkan di sebagian jalan seperti di Jl. Gejayan. Lebarriya median mengurangi lebar badan jalan yang dipakai oleh para pemakai sementara terclapat parkir di kedua sisi jalan dan volume kendaraan yang lewat tinggi.

Penilaian potensi macet pengamatan kedua, diasumsikan semua jalan mengalami potensi yang sama dengan pengamatan pertama, kecuali untuk sebagian jalan yang mengalami perubahan disebabkan karena penggunaan lahan tepi jalan berupa mesjid contohnya pada Jl. Mataram. Penggunaan lahan berupa sekolah, volume lalulintas pada siang hari juga mengalami perubahan sebab ada sebagian sekolah yang lebih awal tutup dibanding dengan hari biasa, contoh terlihat pada Jl. Tentara Pelajar. Penilaian potensi macet hari ketiga diwakili oleh Jl. Suroto dan Jl. Malioboro, alasannya bahwa pada kedua jalan tersebut penggunaan lahan didominasi oleh kantor dan pertokoan.

\section{Manfaat Citra Quickbird dan Sistem Informasi Geografis}

Parameter kemacetan lalulintas yang dapat disadap dari citra Quickbird yaitu jenis penggunaan lahan tepi jalan, kondisi trotoar, kondisi parkir, bentuk persimpangan, dan unsur geometrik jalan yang meliputi lebar jalan, dan panjang jalan. Tingkat kete!itian interpretasi citra Quickbird untuk pengumpulan data penggunaan lahan mencapai $98,6 \%$ dan ketelitian interpretasi dapat dikategorikan sangat baik. Tingkat ketelitian interpretasi citra Quickbird untuk penyadapan data lebar jalan dilakukan dengan melakukan pengukuran lebar ruas jalan pada citra dengan menggunakan ArcView 3.2. Berdasarkan hasil interpretasi, maka diperoleh tingkat ketelitian mencapai 98,19\%.

Perolehan informasi bentuk persimpangan, persimpangan dengan kanalisasi relatif lebih mudah dikenali dari citra sebab ada kenampakan ciri bangunan, sedangkan untuk persimpangan asimetris dan simetris cilakukan pengukuran di pusat persimpangan. Kenampakan trotoar yang diperoleh dari citra dan dilakukan pengecekan lapangan untuk melihat fungsinya, sedangkan hasil interpretasi kenampakan kondisi parkir dapat diidentifikasi sudut parkir moda tertentu khususnya mobil di suatu ruas jalan yaitu $0^{\circ}$ dan $45^{\circ}$ sehingga nilai pengharkatan kondisi parkir untuk jenis moda tertentu dapat ditentukan dari citra Quickbird yang diperkuat dengan hasil kerja lapangan.

Meskipun mempunyai banyak keunggulan, tetapi citra Quickbird mempunyai keterbatasan dalam menyadap sebagian variabel penyebab kemacetan lalulintas. Variabel yang tidak dapat disadap dari citra Quickbird 
yaitu rambu dan volume lalulintas puncak yang dimasukkan ke dalam formula untuk perhitungan tingkat pelayanan jalan, kapasitas jalan, dan derajat kejenuhan.

Data dan informasi tentang parameter penyebab kemacetan lalulintas yang diperoleh pada citra Quickbird maupun dengan hasil kerja lapangan merupakan data atribut setiap jalan dan disajikan dalam peta yang membuat hasil perhitungan masing-masing parameter tersebut yaitu peta potensi kemacetan lalu lintas dan dapat dilihat pada Gambar 4, Gambar 5, dan Gambar 6. Data grafis yang berupa peta potensi kemacetan beserta data atributnya yang dijadikan sebagai dasar untuk manajemen lalulintas.

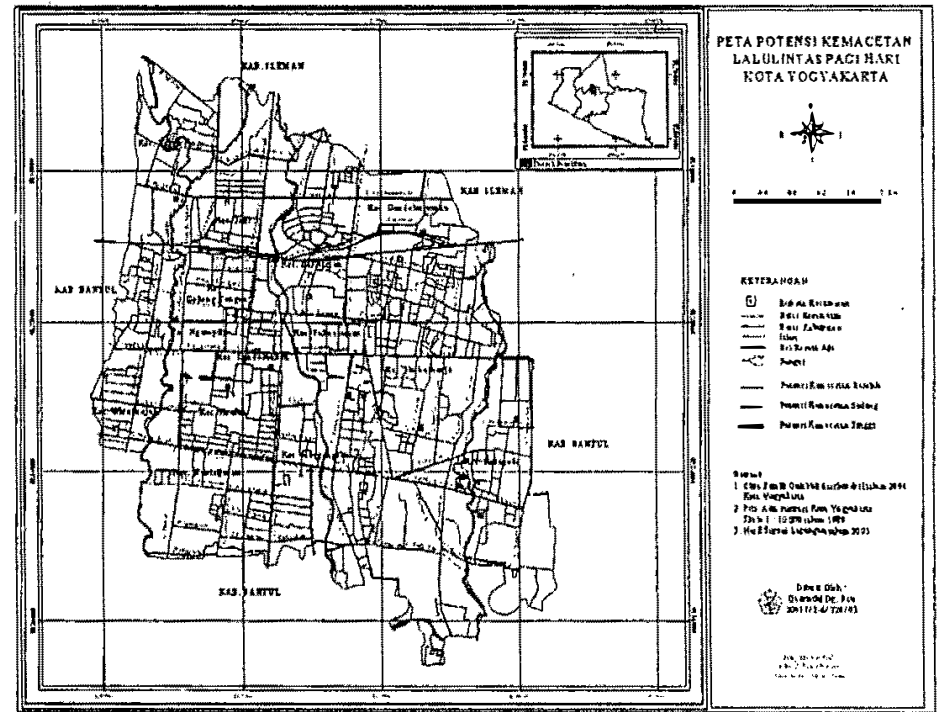

Gambar 4. Peta Potensi Kemacetan Lalulintas Pagi Hari 
Penggunaan Citra Quickbird dan SIS Untuk Perolehan Data Spasial Guna Mendukung Manajemen Lalulintas di Kota Yogyakarta

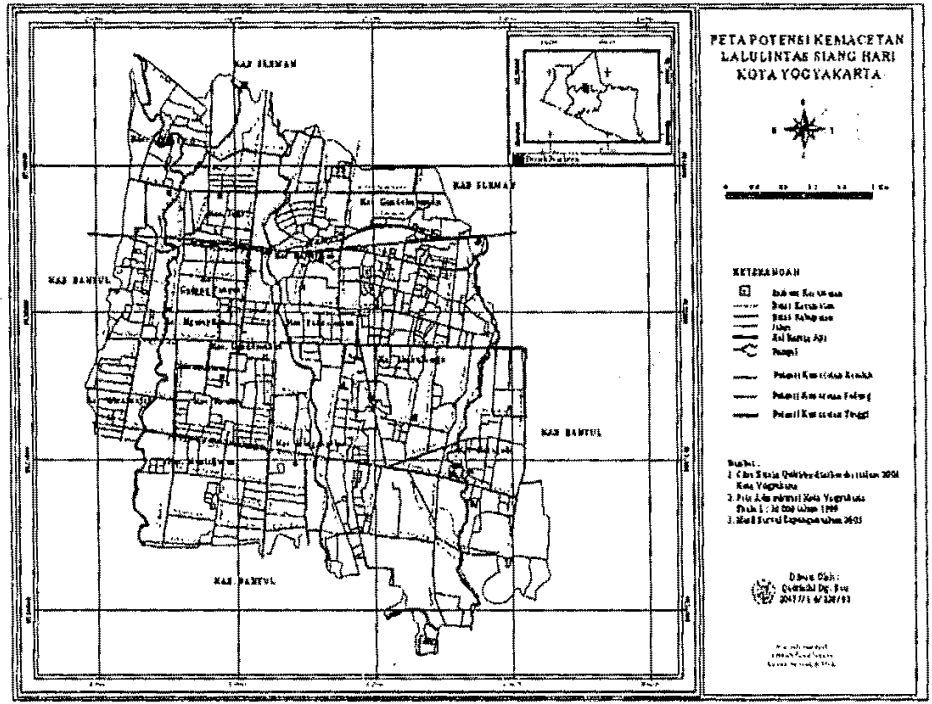

Gambar 5. Peta Potensi Kemacetan Lalulintas Siang Hari

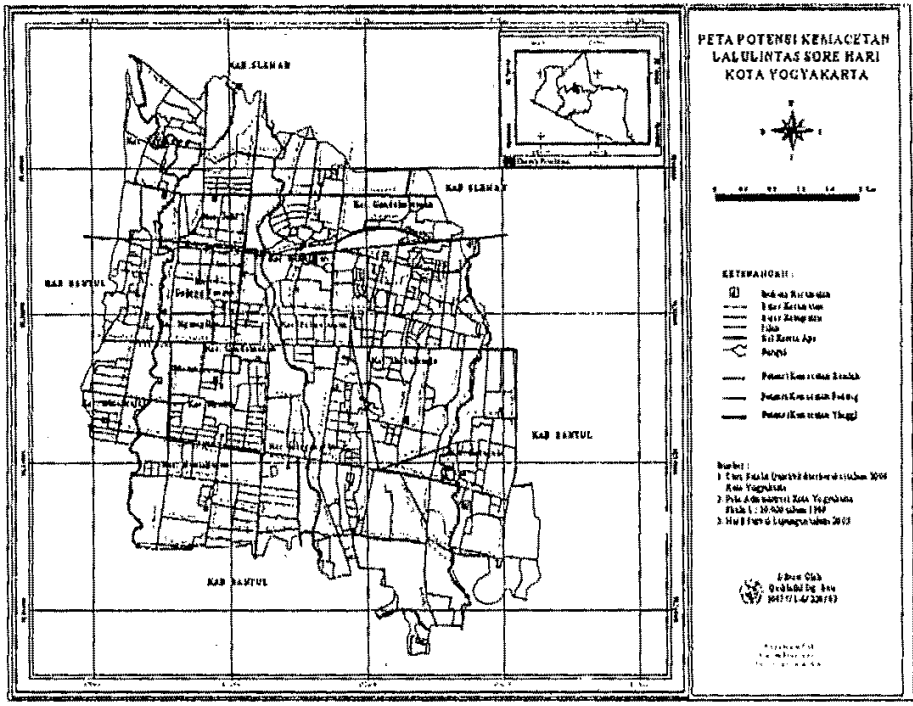

Gambar 6. Peta Potensi Kemacetan Lalulintas Sore Hari 


\section{Pemecahan Masalah Lalullintas}

Masalah kemacetan lalulintas yang terjadi pada ruas jalan pada daerah penelitian dapat diminimalkan dengan menerapkan beberapa strategi manajemen lalulintas. Manajemen lalulintas berupa pelarangan parkir di tepi jalan untuk kedua sisi dapat diterapkan di J. Diponegoro, J. Parang Tritis, Jl. Sisingamangaraja, Jl. A.M. Sangaji, Jl. Prof. Herman Yohanes, dan J. Gejayan, hal ini agar penyusutan badan jalan akibat pengaruh parkir dapat diminimalkan dengan hanya menggunakan satu sisi jalan saja. Pengalihan tempat parkir pada jam sibuk khususnya pagi hari juga dapat dilakukan pada J. Gejayan, J. A.M. Sangaji, J. Diponegoro, J. Parang Tritis, dan Jl. Sisingamangaraja, area parkir dipindahkan ke jalan yang fungsinya sebagai jalan lokal dan tidak dilalui oleh kendaraan umum.

Manajemen Ialulintas lain yang dapat diterapkan antara lain sistem pengontrolan lalulintas yaitu larangan parkir pada tepi jalan untuk jangka waktu tertentu ataupun pembatasan waktu parkir dimaksudkan untuk memberi kesempatan lebih banyak kendaraan parkir di suatu tempat ataupun dengan pemberian tarif (pricing) parkir berdasarkan waktu parkir dengan perbedaan tarif parkir pada daerah arus Ialulintas tinggi ataupun dengan pemberian aturan pada penyelenggara pertokoan besar untuk diwajibkan menyediakan tempat parkir bagi pengunjungnya. Hal ini dapat diterapkan pada J. Urip Sumohardjo, J. Prof Herman Yohanes, Jl. Parang Tritis, Jl. Sisingamangaraja, Jl. Gejayan, dan J. Kusumanegara yang penggunaan lahan sebagian besar pasar, pertokoan, dan pusat perdagangan.

Manajemen Ialulintas berupa pembatasan area operasi kendaraan umum pada vaktu tertentu dapat dilakukan pada J. Malloboro, dan J. Ahmad Yani agar moda kendaraan umum tidak bercampur dengan moda kendaraan pribadi. Lebar jalan pada kedua jalan tersebut tidak dapat menampung volume la'ulintas yang banyak pada jam sibuk. Peninjauan kembali rambu lalulintas agar jalan lokal yang terdapat di ruas jalan tersebut dapat digunakan untuk pengalihan arus kendaraan khususnya pada jam puncak, ataupun dengan menerapkan jalan paralel menjadi arus searah dapat diterapkan juga di J. Herman Yohanes. Manajemen Ialulintas berupa pelarangan kendaraan berat atau kendaraan barang lewat selama jam siouk dapat diterapkan pada J. Mayor Suryotomo sebab keluar masuknya kendaraan pada jalan lokal yang berada di sekitar jalan tersebut dapat menyebabkan macet. 
Manajemen lalulintas berupa sistem pengontrolan lalulintas dengan penggunaan jalur juga dapat diterapkan, yaitu pembatasan minimal penumpang untuk kendaraan pribadi yang akan memasuki Kota Yogyakarta agar pemakai kendaraan pribadi yang tempat tinggalnya berdekatan serta mempunyai tujuan yang berdekatan dapat menggunakan satu kendaraan saja sehingga mengurangi kerapatan lalulintas. Sistem pengontrolan ini dapat diterapkan pada Jl. Kyai Mojo. Pembatasan aktivitas dari penggunaan lahan yang menggunakan tepi jalan atau trotoar untuk keperluan pedagang kaki lima juga bisa diterapkan agar trotoar kembali pada fungsinya untuk pejalan kaki, hal ini dapat diterapkan pada J. Herman Yohanes, J. Dr. Wahidin.

Manajemen lalulintas dengan modifikasi operasi angkutan umum juga dapat diterapkan untuk jalan-jalan yang berpotensi macet dan dilalui angkutan umum, hal ini untuk mempertinggi daya tarik angkutan umum agar masyarakat dari golongan tuawah sampai golongan atas tertarik untuk menggunakannya, ataupun modifikasi angkutan umum dengan menjadikan beberapa tingkatan seperti penambahan moda berupa mikrolet yang kapasitasnya hanya 12 orang dan pembatasan umur kendaraan layak beroperasi akan mempertinggi daya tarik bus dengan kapasitas sekitar 40 orang untuk umur bus tersebsut sudah tua. Manajemen lalulintas berupa tarif pada angkutan umum dapat diberlakukan, misalnya dengan pemberlakuan karcis bulanan dimana karcis tersebut dapat digunakan selama sebulan dan harganya relatif lebih murah daripada jika harus membayar setiap hari sehingga diharapkan masyarakat akan lebih sering memakai angkutan umum atau dengan membuat jalur khusus bagi bus umum.

\section{Periutup}

Citra Quickbird dapat digunakan untuk menyajikan beberapa parameter yang berkaitan dengan kemacetan lalu lintas. Dari 8 parameter yang digunakan maka 5 parameter dapat disadap dari interpretasi citra Quickbird, yaitu: unsur geometrik jalan yang dipakai sebagai dasar dalam perhitungan tingkat pelayanan dan derajat kejenuhan, penggunaan lahan, bentuk persimpangan, trotoar, dan kondisi parkir, dengan tingkat ketelitian 98,6\% untuk hasil interpretasi penggunaan lahan dan $98,19 \%$ untuk hasil interpretasi penyadapan data lebar jalan. 
Kelas potensi kemacetan Ialulintas dibagi dalam tiga kelas, yaitu tinggi, sedang, dan rendah. Pemecahan masalah terhadap kemacetan menggunakan manajemen lalulintas meliputi beberapa hal, yaitu pelarangan parkir di tepi jalan, larangan parkir pada tepi jalan untuk jangka waktu tertentu ataupun pembatasan waktu parkir, pembatasan area operasi kendaraan umum, peninjauan kembali rambu lalulintas, menerapkan jalan paralel menjadi arus searah, kendaraan berat atau kendaraan barang lewat selama jam sibuk, pembatasan minimal penumpang untuk kendaraan pribadi, pembatasan aktivitas dari penggunaan lahan yang menggunakan tepi jalan atau trotoar untuk keperluan pedagang kaki lima, modifikasi operasi angkutan umum, tarif pada angkutan umum dapat diberlakukan, modifikasi angkutan umum dengan menjadikan beberapa tingkatan, dan membuat jalur khusus bagi bus umum.

\section{Daftar Pustaka}

Ahmad Munawar. 2004. Manajemen Lalulintas Perkotaan. Yogyakarta: Penerbit Beta Offset.

Anonimus. 2003. Kota Yogyakarta dalam Angka. Yogyakarta: Biro Pusat Statistik.

Dirıktorat Jenderal Bina Marga. 1997. Manual Kapasitas Jalan Indonesia. Jakarta : Ditjen Bina Marga dan Sweroad.

Dulbahri. 2003. Analisis Digital Data Penginderaan Jauh. Yogyakarta:

Puspics, Fakultas Geografi Universitas Gadjah Mada.

Malinggreau J.F. 1982. A Propose Land Use/Land Cover Classification System for Indonesian. The Indonesian Journal of Geography, Faculty of Geography, Gadjah Mada University. Yogyakarta. 
Penggunaan Citra Quickbird dan SIC, Untuk Perolehan Data Spasial Guna Mendukung Manajemen

Ialulintas di Kota Yoiryairarta

Prahasta Eddy. 2002. Konsep-Konsep Dasar Sistem Informas/ Geografis. Bandung: Penerbii Informatika.

Tamin 0. Z. 2000. Perencariaan dan Pemodelan Transportasi. Bandung: Penerbit ITB. 